\title{
ANALISIS I-HDI (ISLAMIC-HUMAN DEVELOPMENT INDEX) DI JAWA TIMUR')
}

\author{
Maya Masita Septiarini \\ Mahasiswa Program Studi S1 Ekonomi Islam-Fakultas Ekonomi dan Bisnis-Universitas Airlangga \\ Email:maya.masita-12@feb.unair.ac.id
}

Sri Herianingrum

Departemen Ekonomi Syariah-Fakultas Ekonomi dan Bisnis-Universitas Airlangga

Email: sri.herianingrum@feb.unair.ac.id

\begin{abstract}
:
This research aims to analyze the human development achievement in East Java in 2010-2014 which is measured based on islamic-human development index. This research also compares towards the human development achievement based on HDI (Human Development Index) and I-HDI. The research method used in this research is descriptive qualitative with 11 secondary data from BPS/Central Statistic Body and two calculation data from I-HDI. The result from the calculation of I-HDI shows that the majority of cities kota/regencies in East Java during 2010-2014 were in mid end to low end category, with relatively far disparity among regencies/cities. Meanwhile, from the result of calculation of $\mathrm{HDI}$, mostly the human development achievement in East Java were in mid end to high end category. This explains that I-HDI is more comprehensive in measuring the human development achievement compared to I-HDI.
\end{abstract}

\section{Keywords : Maqashid syariah, I-HDI, HDI, human development disparity}

\section{PENDAHULUAN}

\section{Latar Belakang}

Paradigma pembangunan yang sedang berkembang saat ini adalah pertumbuhan ekonomi yang di ukur dengan pembangunan manusia yang dilihat dengan tingkat kualitas hidup manusia di tiap-tiap negara. Persoalan tentang pencapaian pembangunan sejuh ini telah menjadi perhatian penyelenggara pemerintahan. Berbagai ukuran pembangunan manusia dibuat namun tidak semuanya dapat digunakan sebagai ukuran standar yang dapat dibandingkan antar wilayah atau antar negara. Maka dari itu, Badan Perserikatan Bangsa-Bangsa (PBB) menetapkan suatu ukuran standar pembangunan manusia yaitu Human Development Index (HDI) atau disebut juga dengan Indeks 1) Jurnal ini merupakan bagian dari skripsi Maya Masita S, NIM: 041211433057, yang diuji pada tanggal 12 Agustus 2016
Pembangunan Manusia (IPM) yang diukur melalui kualitas tingkat pendidikan, kesehatan dan ekonomi (daya beli).

Melalui peningkatan ketiga indikator tersebut diharapkan akan terjadi peningkatan kualitas hidup manusia. Namun demikian, keberhasilan pembangunan manusia tidak dapat dilepaskan dari kinerja pemerintah yang berperan dalam menciptakan regulasi bagi tercapainya tertib sosial. Namun persoalannya adalah pencapaian pembangunan manusia secara parsial sangat bervariasi dimana beberapa aspek pembangunan tertentu berhasil dan beberapa aspek pembangunan lainnya gagal. Sehubungan dengan hal itu, maka bagaimana menilai 
Septiarini, et al/Jurnal Ekonomi Syariah Teori dan Terapan Vol. 4 No. 5 Mei 2017: 381-395; ANALISIS I-HDI (ISLAMICHUMAN DEVELOPMENT INDEX) DI JAWA TIMUR

keberhasilan pembangunan manusia Pembangunan manusia atau peningkatan kualitas sumber daya manusia menjadi hal yang sangat penting dalam strategi kebijakan pembangunan nasional. Penekanan terhadap pentingnya peningkatan sumber daya manusia dalam pembangunan menjadi suatu kebutuhan karena kualitas manusia di suatu wilayah memiliki andil besar dalam menentukan keberhasilan pengelolaan pembangunan wilayahnya, dan keberadaan HDI yang ditawarkan oleh United Nations Development Program (UNDP) sebagai salah satu alat yang dapat di pakai untuk mengukur tingkat pembangunan manusia mungkin dapat menjadi indikator yang paling komprehensif, tetapi tidak sepenuhnya kompatibel dan cukup untuk mengukur pembangunan manusia dalam perspektif Islam. Teori dan konsep yang mendasari untuk membangun HDI tidak didasarkan pada maqashid syariah. Untuk mengukur tingkat pembangunan manusia di negara yang mayoritas penduduknya beragama Islam akan lebih tepat jika dilakukan dengan menggunakan Islamic Human Development Index (I-HDI), yang mana teori dan konsepnya berdasarkan pada perspektif Islam.

Berdasarkan penelitian yang dilakukan oleh Anto dalam Intruduction an Islamic Human Development Index (IHDI) to Measure Development in OIC Countries (2009) dan Rafsanjani dalam Analisis I-HDI di Indonesia (2014), I-HDI di hitung berdasarkan data yang secara komperhensif?

menggambarkan kelima dimensi maqashid syariah tersebut. Untuk dimensi agama (ad-dien) indikator yang digunakan yaitu data angka kriminalitas dan angka partisipasi siswa sekolah agama. Dimensi jiwa (an-nafs) indikator yang dipakai yaitu data angka harapan hidup. Semetara itu, untuk dimensi intelektual (al'-aql) digunakan indikator yaitu data angka melek huruf dan ratarata lama sekolah. Untuk dimensi keturunan (an-nasl) digunakan dua indikator yaitu data angka kelahiran total dan angka kematian bayi. Untuk dimensi harta (al-maal) maka digunakan gabungan dua indikator yaitu indikator kepemilikan harta oleh individu dan indikator distribusi pendapatan. Untuk indikator kepemilikan atas harta data yang dipakai yaitu pengeluaran perkapita riil disesuaikan, untuk indikator distribusi pendapatan digunakan data indeks gini dan indeks kedalaman kemiskininan.

Jawa timur merupakan salah satu provinsi DI Indonesia yang jumlah penduduk beragama Islamnya banyak. Data menunjukkan berdasarkan sensus penduduk yang dilakukan tahun 2010 jumlah penduduk Jawa Timur beragama Islam \pm 36 juta jiwa. Juga kultur di Jawa Timur lekat dengan ajaran Islam, oleh sebab itu I- HDI sangat relevan bila digunakan dalam pengukuran kesejahteraan manusia di Jawa Timur.

Atas dasar inilah, peneliti tertarik melakukan analisis I-HDI di Jawa Timur khususnya pada periode 2010-2014. 
Adapun tujuannya untuk mengetahui pencapaian pembangunan manusia di Jawa Timur yang diukur dengan I-HDI dan juga perbandingannya dengan hasil perhitungan HDI.

\section{LANDASAN TEORI}

Pada dekade 1990-an, definisi pembangunan telah semakin berkembang dengan didukung oleh pembangunan manusia (human development) sehingga terbentuk definisi pembangunan yang berorientasi pada manusia (people centered development) (Sumarsono, 2002). Difinisi pembangunan yang berorientasi pada manusia ini disebut juga dengan paradigma pembangunan manusia (Syukir, 2008 dalam Castrenaningtyas (2011: 19)). Dalam salah satu publikasi resminya, Bank Dunia (1991) dalam Castrenaningtyas (2011: 19) yang selama dekade 1980-an menjunjung tinggi pertumbuhan ekonomi sebagai tujuan utama pembangunan akhirnya melakukan redefinisi dengan pernyataan sebagai berikut :

Tantangan

utama pembangunan adalah memperbaiki kualitas kehidupan. Pertama di negaranegara yang paling miskin, kualitas hidup yang lebih baik memang mensyaratkan adanya pendapatan yang tinggi, namun yang dibutuhkan bukan hanya itu. Pendapatan yang lebih tinggi hanya merupakan salah satu dari banyak syarat yang harus dipenuhi. Banyak hal lain yang juga harus diperjuangkan, yakni pendidikan yang lebih baik, peningkatan standar kesehatan dan nutrisi, pemberantasan kemiskinan, perbaikan kondisi lingkungan hidup, pemerataan kesempatan, peningkatan kebebasan individual, dan pelestarian ragam kehidupan budaya.
Menurut Amartya Sen (1999), pertumbuhan ekonomi dengan sendirinya tidak bisa dianggap sebagai tujuan terakhir. Pembangunan haruslah lebih memperhatikan peningkatan kualitas kehidupan yang kita jalani dan kebebasan yang kita nikmati. Hal terpenting bukanlah apa yang dimiliki oleh seseorang, tetapi apakah yang dapat dilakukan seseorang dengan barang-barang tersebut. Manfaat dari sebuah komoditi inilah yang menurut Sen dapat mempengaruhi kesejahteraan. Konsep ini disebut juga dengan pendekatan kapabilitas dari Sen.

$$
\text { Dalam buku Pembanguna }
$$

Ekonomi di Dunia Ketiga, Todaro (2003: 28) menuliskan bahwa terdapat tiga komponen dasar atau nilai inti yang harus dijadikan basis konseptual dan pedoman praktis untuk memahami arti pembangunan, yakni peningkatan ketersediaan serta perluasan distribusi berbagai macam barang kebutuhan yang pokok (sandang, pangan, papan, kesehatan, keamanan), penigkatan standar hidup, serta perluasan pilihanpilihan ekonomis dan sosial. Ketiga nilai inti tersebut berkaitan secara langsung dengan kebutuhan-kebutuhan manusia yang paling mendasar, yang terwujud dalam berbagai manifestasi di hampir semua masyarakat dan budaya sepanjang jaman.

Ahmad (1980 dan 1994) dalam Rafsanjani (2014: 12), pada tulisannya menguraikan empat filosofis dasar-dasar 
pendekatan Islam dalam pembangunan, yaitu:

1)Tauhid, 2) Rububbiyyah, 3) Khilafah, dan 4) Tazkiyah, serta fitur penting dari konsep pembangunan Islam, sebagai berikut (Ahmad 1980 dan 1994 dalam Rafsanjani (2004:13)) :

1. Pembangunan ekonomi dalam Islam bersifat komprehensif dan mengandung unsur spiritual, moral dan material. Pembangunan merupakan aktivitas yang berorientasi pada tujuan dan nilai. Aspek material, moral, ekonomi, sosial spiritual dan fiskal tidak dapat dipisahkan. Kebahagiaan yang ingin di capai tidak hanya kebahagiaan dan kesejahteraan material di dunia, tahmetapi juga di akhirat.

2. Fokus utama pembangunan adalah manusia dengan lingkungan kulturnya. Ini berbeda dengan konsep pembangunan ekonomi modern yang menegaskan bahwa wilayah operasi pembangunan adalah lingkungan fisik saja. Dengan demikian Islam memperluas wilayah jangkauan obyek pembangunan dari lingkungan fisik kepada manusia.

3. Pembangunan ekonomi adalah aktivitas multidimensional sehingga semua usaha harus diserahkan pada keseimbangan berbagai faktor dan tidak menimbulkan ketimpangan.

4. Pembangunan ekonomi melibatkan sejumlah perubahan, baik secara kuantitatif maupun kualitatif, dan seimbang antara satu sama lain.
Penekanan utama dalam pembangunan menurut Islam, terletak pada; a) pemanfaatan sumber daya yang telah diberikan Allah kepada ummat manusia dan lingkungannya semaksimal mungkin, b) pemanfaatan sumber daya tersebut melalui pembagian, peningkatannya secara syukur dan adil dan mengutuk sikap kufur dan zalim.

Maqashid Syariah adalah hal- hal dasar yang harus dipenuhi manusia demi mencapai falah, yaitu kebutuhan di dunia dan di akhirat. Tanpa memenuhi seluruh hal tersebut, maka manusia tidak akan mendapatkan kebahagiaan yang sempurna (al-Syatibi). Kebutuhan dasar tersebut mencakup lima pokok kemaslahatan dengan peringkatnya masing- masing. Kelima pokok tersebut dijelaskan sesuai dengan urutannya yaitu agama, jiwa, akal, keturunan dan harta yang kemudian digolongan lagi menjadi tiga kelompok kebutuhan, yaitu dharuriyyah, hajiyah, dan tashiniyyah yang akan dijelaskan berdasarkan tingkat kepentingan atau kebutuhannya Djamil (1995: 41-44).

UNDP mendefinisikan pembangunan manusia sebagai proses memperluas kesempatan dan kebebasan masyarakat untuk menentukan pilihannya dalam pemenuhan kebutuhan dasar dan upaya memperbaiki tingkat penghargaan terhadapa eksistensi masing-masing masyarakat sebagai manusia (Srinivasan, 1994). Kebutuhan dasar yang dimaksud adalah kebutuhan untuk mendapatkan 
pendidikan, hidup lebih lama dan sehat, serta dengan mudah mengakses segala sumber daya yang diperlukan sebagian pemenuhan standar hidup layak.

Indeks Pembangunan Manusia atau Human Development Index (HDI) merupakan indikator yang dogunakan untuk mengukur salah satu aspek penting yang berkaitan dengan kualitas dari hasil pembangunan, yaitu derajat perkembangan manusia (Tambunan, 2003:167). Indeks ini merupakan gabungan atas tiga kriteria sebagai output yang diharapkan dari proses pembangunan (UNDP, 2004):

1. Ketahanan hidup, yang diukur dari angka harapan hidup (Life Expectancy/ LE) penduduk di suatu wilayah.

2. Pengetahuan yang diukur berdasarkan tingkat rata-rata melek huruf penduduk dewasa dengan bobot dua per tiga dan angka ratarata lama masa sekolah penduduk di suatu wilayah dengan bobot sepertiga.

3. Kualitas standar hidup diukur berdasarkan pendapatan perkapita riil yang disesuaikan dengan paritas daya beli (purchasing power parity, PPP) dari mata vang domestik masing-masing wilayah.

I-HDI merupakan alat yang digunakan untuk mengukur pembangunan manusia dalam perspektif Islam. I-HDI mengukur pencapaian tingkat kesejahteraan manusia dengan terpenuhinya kebutuhan dasar agar manusia dapat hidup bahagia di dunia dan akhirat (mencapai falah). Menurut alSyatibi, mashlahah dasar bagi kehidupan manusia terdiri dari lima hal, yaitu agama (ad-dien), jiwa (an-nafs), akal (al-'aql), keturunan (An-nasl), dan harta (al-maal). Kelima hal tersebut merupakan kebutuhan dasar manusia, yaitu kebutuhan yang mutlak harus dipenuhi agar manusia dapat hidup bahagia di dunia dan akhirat. Jika salah satu dari kebutuhan dasar di atas tidak terpenuhi atau terpenuhi dengan tidak seimbang niscaya kebahagiaan hidup juga tidak tercapai dengan sempurna (P3El: 2012, 5-6).

Tabel 1.

Lima Indeks yang Diusulkan

\begin{tabular}{|c|c|c|}
\hline Tujuan Pembanguna & Dimensi & Indeks Dimensi \\
\hline \multirow{4}{*}{ Maslahah } & Hifdzu ad-Dien & Index ad-Dien \\
\cline { 2 - 3 } & Hifdzu an-Nafs & Indekx an-Nafs \\
\cline { 2 - 3 } & Hifdzu al-Aqq & Index al-Aql \\
\cline { 2 - 3 } & Hifdzu an-Nasl & Index an-Nasl \\
\cline { 2 - 3 } & Hifdzu al-Maal & Index-al-Maal \\
\hline
\end{tabular}

Sumber: Anto, 2009. Introduction an Islamic Human Development Index (I-HDI) to Measure Developmen in OIC Countries, disesuaikan, dalam Rafsanjani, 2014. Analisis Islamic Development Index di Indonesia.

mengukur kelima dimensi tersebut dibentuklah suatu indeks yang mewakili dari masing-masing dimensi tersebut dibentuklah suatu indeks yang diusulkan untuk mengukur kelima dimensi tersebut yaitu: index ad-dien yang mewakili dimensi agama, index an-nafs yang mewaili dimensi umur panjang dan sehat, index al-'aql yang mewakili dimensi 
pengetahuan, index an-nasl yang mewakili dimensi keluarga dan keturunan, dan index al-maal yang mewakili dimensi pendapatan.

Tabel 2.

Kesejahteraan Holistik dengan Indikator yang Diusulkan

\begin{tabular}{|c|c|c|c|}
\hline Kesejajterman & Dimensi & ndeles Dimensi & Indikator \\
\hline \multirow{3}{*}{ Material Walfare Inder (MVII) } & \multirow{3}{*}{ Hittala al-Maal } & \multirow{3}{*}{ Inder a a-Yanal } & 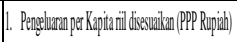 \\
\hline & & & Rsisioniin \\
\hline & & & 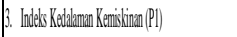 \\
\hline \multirow{7}{*}{ Non-Naterial Walfare Inder: (NTII) } & \multirow{2}{*}{ Hiftay ad-Dien } & \multirow{2}{*}{ Inder a ad.Dien } & 1. Angak diminaditis \\
\hline & & & 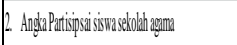 \\
\hline & \multirow{2}{*}{ Hiftalu al:Agl| } & \multirow{2}{*}{ |Inderal'Agl } & 1. Angay Mek Hinuf \\
\hline & & & 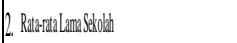 \\
\hline & Hitfald an-Nats & if Index an.Nots & 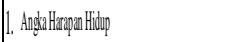 \\
\hline & \multirow{2}{*}{ Hiftalu non-Nasl } & \multirow{2}{*}{ Indexa an-Nasl } & 1. Angak Kedairira Total \\
\hline & & & 2. Angat Kendian Bayi \\
\hline
\end{tabular}

Sumber: Anto, 2009. Introduction an Islamic Human Development Index (I-HDI) to Measure Developmen in OIC Countries, disesuaikan, dalam Rafsanjani, 2014. Analisis Islamic Development Index di Indonesia.

\section{METODE PENELITIAN}

Penelitian ini menggunakan metode penelitian kualitatif. Metode penelitian kualitatif merupakan metode penelitianyang berlandaskan pada filsafat postpositivisme, atau paradigma interpretatif dan konstruktif, yang memandang realitas sosial sebagai suatu yang holistik atau utuh, kompleks, dinamis, penuh makna dan hubungan gejala bersifat interaktif dan digunakan untuk meneliti pada kondisi obyek yang alamiah, bukan eksperimen, di mana peneliti sebagai instrumen kunci, teknik pengumpulan data dilakukan secara triangulasi (gabungan), analisis dan bersifat induktif atau kualitatif dan hasil penelitian lebih menekankan makna dari pada generalisasi (Sugiyono, 2013:9).

Adapun pendekatan yang dipakai dalam penelitian ini yaitu kualitatif deskriptif. Menurut Vardiansah dalam Leksono (2013:181) penelitian deskriptif adalah upaya pengolahan data menjadi sesuatu yang dapat diutarakan secara jelas dan tepat dengan tujuan agar dapat dimengerti oleh orang yang tidak langsung mengalaminya sendiri. Berdasarkan pada hal itu, maka yang dimksud dengan penelitian kualitatif deskriptif adalah sebuah pendekatan terhadap sesuatu perilaku, fenomena, peristiwa, masalah atau keadaan tertentu yang menjadi obyek penyelidikan yang hasil temuannya berupa uraian-uraian kalimat bermakna yang menjekaskan pemahaman tertentu.

Alasan pemilihan metode penelitian kualitatif deskriptif karena penelitian ini bertujuan untuk mendeskripsikan pencapaian pembangunan manusia dari hasil pengukuran I-HDI di Jawa Timur periode 2010-2014 dengan menggunakan data sekunder, yaitu berupa data-data statistik sosial-ekonomi (angka kriminalitas, angka partisipasi siswa sekolah agama, angka harapan hidup, angka melek huruf, rata-rata lama sekolah, angka kematian bayi, angka kelahiran total,daya beli, indeks gini, tingkat kedalaman kemiskinan, dan indeks demokrasi) yang diambil dari Badan Pusat Statistik (BPS) di Jawa Timur periode 2010-2014. 


\section{Obyek Penelitian}

Penelitian ini menggunakan waktu pengamatan selama lima tahun yang selama periode 2010-2014, dan yang menjadi obyek penelitian adalah 38 kota/kabupaten di Jawa Timur.

\section{Fokus Penelitian}

Penentuan fokus dalam penelitian kualitatif yang di maksud adalah membatasi studi kualitatif (Moeleong, 2004: 94), maksudnya adalah bahwa penentuan fokus penelitian diperlukan untuk membatasi studi kulitatif agar pembahasannya tetap fokus pada permasalahan yang sedang diteliti, bukan sebaliknya. Fokus dalam studi kualitatif ini adalah pencapaian pembangunan manusia 38 kabupaten/kota di Jawa Timur yang diukur dengan I-HDI.

\section{Sumber Data}

Sumber data yang digunakan dalam penelitian ini adalah sumber data sekunder. Data sekunder merupakan sumber data yang tidak langsung memberikan data kepada pengumpul data (Sugiyono, 2013: 225). Adapun sumber data yang digunakan dalam penelitian ini yaitu sata statistik sosialekonomi dari 37 kota/kabupaten di Jawa Timur periode 2010-2014. Beberapa yang diambil meliputi:

1. Angka kriminalitas

2. Angka Partisipasi Siswa Sekolah Agama

3. Angka harapan hidup

4. Angka melek hurug

5. Rata-rata lama sekolah

6. Angka kelahiran total
7. Angka kematian bayi

8. Pengeluaran perkapita riil desesuaikan

9. Indeks gini

10. Indeks kedalaman kemiskinan

11. Indeks pembangunan manusia

Data angka kelahiran total disesuaikan dengan angka kematian bayi, islamic human development index, material welfare dan non-mterial walfare dalam penelitian ini diperoleh dari hasil perhitungan indeks dengan menggunakan data-data tersebut di atas.

\section{Teknik Pengumpulan Data}

Teknik pengumpulan data yang digunakan dalam penelitian ini yaitu teknik dokumenter. Teknik dokumenter adalah salah satu metode pengumpulan data kualitatif dengan melihat atau menganalisis dokumen-dokumen yang di buat subyek sendiri atau oleh orang lain. Moleong dalam Herdiansyah (2010: 143), menggunakana dua bentuk dokumen yang dapat dijadikan bahan studi dokumentasi, yaitu:

1. Dokumentasi pribadi

Dokumentasi pribadi adalah catatan atau karangan seseorang secara tertulis tentang tindakan, pengalaman, dan kepercayaannya. Tujuan dari dokumentasi ini adalah untuk memperoleh sudut pandang orisisnil dari kejadian situasi nyata.

2. Dokumen resmi

Menurut Moleong dalam Herdiansyah (2010: 145-146). Dokumen resmi dapat dibagi kedalam dua bagian. 1) dokumen internal, yaitu dapat berupa catatan, seperti memo, 
pengumuman, instruksi, aturan suatu lembaga, sistem yang diberlakukan, hasil notulensi rapat keputusan pimpinan dll. 2) dokumentasi eksternal yaitu dapat berupa bahan-bahan informasi yang dihasilkan oleh suatu lembaga seperti, majalah, koran, bulletin, dll.

Adapun bentuk dokumen yan digunakan dalam penelitian ini yaitu dokumen remi ekstetnal, karena dokumen yang diambil berupa data-data statistik sosial ekonomi Jawa Timur yang diambil dari publikasi Badan Pusat Statistik (BPS) Jawa Timur.

\section{Teknik Analisis Data}

Teknik analisis data yang digunakan dalam penelitian ini adalah model interakif. Lebih lanjut Miles dan Hubberman dalam bukunya Sugiyono, 2013: 246-252, mengemukakan bahwa analisis dengan menggunakan analisis model interaktif dilakukan melalui tiga prosedur, yaitu:

\section{Reduksi Data}

Merduksi data berarti merangkum, memilih hal-hal yang pokok, memfokuskan pada hal-hal yang penting, dicari tema dan polanya. Data yang telah di reduksi akan memberikan gambaran yang lebih jelas dan mempermudah peneliti untuk melakukan pengumpulan data selanjutnya bila diperlukan.

\section{Penyajian Data}

Setelah data direduksi, maka langkah selanjutnya adalah menampilkan data. Dala hal ini Miles dan Huberman dalam
Sugiyono, 2013: 248, menyatakan bahwa yang paling sering digunakan untuk menyajikan data dalam penelitian kualitatif adalah degan teks yang bersifat naratif.

3. Menarik Kesimpulan (verifikasi)

Langkah ketiga dalam analisis data kualitatif menurut Miles dan Huberman dalam Sugiyono, 2013: 248, adalah penarikan kesimpulan dan verifikasi. Kesimpulan awal yang dikemukakan masih bersifat sementara, dan akan berubah bila tidak ditemukan bukti-bukti yang kuat yang mendukung pada tahap pengumpulan data berikutnya. Tetapi apabila kesimpulan yang dikemukakan pada tahap awal, didukung oleh bukti-bukti yang valid dan konsisten saat peneliti kembali ke lapangan mengumpulkan data, maka kesimpulan yang dikemukakan merupakan kesimpulan yang kredibel.

\section{HASIL DAN PEMBAHASAN}

\section{Hasil Perhitungan Pencapaian HDI}

Pertumbuhan HDI kabupaten/kota di Jawa Timur menunjukkan adanya peningkatan dari tahun 2010-2014. Ratarata nilai $\mathrm{HDI}$ kota/kabupaten secara keseluruhan di Jawa Timur pada tahun 2010-2014 adalah sebesar 65,36; 66,06; 66,74; 67,55; 68,14. Angka tersebut menutupi variasi nilai HDI antar kabupaten/kota, padahal terdapat perbedaan pencapaian antara HDI tertinggi dengan $\mathrm{HDI}$ terendah sekitar 22,71 poin pada tahun 2010; 22,45 poin pada tahun 2011; 22,27 pada tahun 2012; 
22,06 pada tahun 2013; dan 21,98 pada tahun 2014 dengan rentang nilai77,2254,$49 ; 77,62-55,12 ; 78,05-55,78 ; 78,51-56,45$; 78,96-56,98. Masing-masing untuk Kota Surabaya dengan nilai tertinggi dan Sampang untuk nilai terendah pada tahun 2010-2013, serta Kota Malang dengan nilai tertinggi dan Sampang untuk nilai terendah pada tahun 2014.

Secara berturut-turut pada tahun 2010-2013 Kota Surabaya tercatat sebagai daerah dengan pencapaian HDI tertinggi yaitu mecapai 77,$2 ; 77,62$; 78,05; 78,51, diikuti kemudian oleh Kota Malang sebagai urutan kedua yaitu sebesar 76,69;77,36; 78,04; 78,44 dan Kota Madiun yang mencapai 75,98; 76,$48 ; 77,21 ; 78,41$. Sedangkan pada tahun 2014 Kota Malang berada pada peringkat tertinggi dengan nilai sebesar 78,96, diikuti Kota Surabaya dan Kota Madiun dengan nilai HDI sebesar 78,87 dan 78,81 . Secara historis ketiga daerah tersebut selama tahun 2010-2014 menjadi daerah tiga terbaik dalam pencapaian pembangunan manusia di Jawa Timur.

Kabupaten Sampang menjadi daerah dengan pencapaian $\mathrm{HDI}$ terendah selama lima tahun berturut-turut yaitu tahun 2010-2014 dengan nilai mencapai 54,$49 ; 55,17 ; 55,78 ; 56,45 ; 56,98$, kemudian diikuti dengan dua kabupaten lainnya yang memilik nilai HDI terendah secara berturut-turut adalah Kabupaten Bangkalan dan Kabupaten Sumenep, yang mana dari ketiga daerah dengan pencapaian $\mathrm{HDI}$ terendah semuanya berada di Pulau Madura.

Berdasarkan skala internasional, pencapaian HDI dapat dikategorikan menjadi empat: kategori tinggi ( $\mathrm{HDI}>80$ ), kategori menengah atas $(66<\mathrm{HDI}<$ 80 ), kategori menengah bawah (50 $<\mathrm{HDI}<66$ ), dan kategori rendah $(\mathrm{HDI}<50)$.

Tabel 3.

Status HDI Menurut Kabupaten/Kota di Jawa Timur Tahun 2010-2014

\begin{tabular}{|l|c|c|c|c|c|}
\hline \multirow{2}{*}{ Pencapaian HDI } & \multicolumn{5}{|c|}{ Jumlah Kota/Kabupaten } \\
\cline { 2 - 6 } & $\mathbf{2 0 1 0}$ & $\mathbf{2 0 1 1}$ & $\mathbf{2 0 1 2}$ & $\mathbf{2 0 1 3}$ & $\mathbf{2 0 1 4}$ \\
\hline Tinggi (HDI > 80) & 0 & 0 & 0 & 0 & 0 \\
\hline $\begin{array}{l}\text { Menengah Atas (66 } \\
\text { <HDI < 80) }\end{array}$ & 16 & 18 & 23 & 23 & 24 \\
\hline $\begin{array}{l}\text { Menengah Bawah } \\
\text { (50 < HDI < 66) }\end{array}$ & 22 & 20 & 15 & 15 & 14 \\
\hline Rendah (HDI < 50) & 0 & 0 & 0 & 0 & 0 \\
\hline
\end{tabular}

Sumber: Publikasi HDI 2010-2014 oleh BPS.

\section{Hasil Perhitungan Pencapaian I-HDI}

Sebaran nilai I-HDI kabupaten/kota di Jawa Timur lebih variatif dan fluktuatif dibanding sebaran nilai $\mathrm{HDI}$, sehingga berpengaruh terhadap peringkat tiaptiap kabupaten/kota di Jawa Timur. Selisih antara peringkat I-HDI tertinggi dengan peringkat I-HDI terendah sekitar 41,66 poin di tahun 2010, 22,72 poin di tahun $2011,33,48$ poin di tahun 2012 , 33,22 poin di tahun 2013, 37,19 poin di tahun 2014. Hasil tersebut menunjukkan perbedaan yang sangat signifikan terhadap jarak antara peringkat tertinggi dan peringkat terendah dari hasil perhitungan HDI yang berkisar pada 22 poin saja. 
Nilai tertinggi di tahun 2010 dicapai oleh Kabupaten Malang dengan nilai sebesar 90,06, kemudian di tahun 201 1hingga 2012 nilai tertinggi di capai oleh Kabupaten Sidoarjo dengan nilai sebesar 82,42 dan 85,90 . Nilai tertinggi di tahun 2013 dicapai oleh Kota Surabaya dengan nilai 82,79, di tahun 2014 nilai tertinggi di capai oleh Kabupaten Jember dengan nilai sebesar 91,35. Sementara itu, Kota Surabaya yang notabene merupakan ibukota Jawa Timur pada tahun 2010 berada pada peringkat 28 dengan nilai sebesar 55,50, naik menjadi peringkat 21 di tahun 2011 dengan nilai sebesar 63,03, di tahun 2012 naik lagi menjadi peringkat 14 dengan nilai sebesar 69,20, di tahun naik lagi menjadi peringkat pertama dengan nilai 82,79, lalu turun dengan drastis menjadi peringkat terakhir dengan nilai sebesar 54,16. Hal ini disebabkan dengan banyaknya kompenen dan indikator dalam perhitungan pencapaian I-HDI yang mana berpengaruh terhadap porsi nilai yang dihasilkan.

Tabel 4.

Status I-HDI Menurut Kabupaten/Kota di Jawa Timur Tahun 2010-2014

\begin{tabular}{|l|c|c|c|c|}
\hline \multirow{2}{*}{ Pencapaian HDI } & \multicolumn{5}{|c}{ Jumlah Kota/Kabupaten } \\
\cline { 2 - 5 } & $\mathbf{2 0 1 0}$ & $\mathbf{2 0 1 1}$ & $\mathbf{2 0 1 2}$ & $\mathbf{2 0 1 3}$ \\
\hline Tinggi (I-HDI > 80) & 2 & 4 & 4 & 1 \\
\hline $\begin{array}{l}\text { Menengah Atas (66 } \\
\text { < I-HDI < 80) }\end{array}$ & 19 & 12 & 14 & 8 \\
\hline $\begin{array}{l}\text { Menengah Bawah } \\
(\mathbf{5 0}<\text { I-HDI < 66) }\end{array}$ & 15 & 22 & 20 & 28 \\
\hline Rendah (I-HDI < 50) & 2 & 0 & 0 & 1 \\
\hline
\end{tabular}

Sumber: Hasil perhitungan I-HDI

\section{Timur}

Analisis mengenai perkembangan pencapaian pembangunan di setiap kabupaten/kota di Jawa Timur yang berdasarkan pada hasil perhitungan I-HDI yang disajikan peneliti pada sub bab 4.2, yang mana dapat diketahui bahwa pencapaian pembangunan dari tiaptiap kabupaten/kota sangat beragam. Berikut ini merupakan penjelasan analisisnya.

1. Kabupaten/kota dengan status I-HDI tinggi $(\mathrm{I}-\mathrm{HDI}>80)$

Selama tahun 2010 hingga 2014 terdapat dua kabupaten/kota di Jawa Timur yang masuk dalam kategori status pembangunan tinggi di tahun 2010, naik menjadi empat di tahun 2011 dan 2012, turun menjadi satu di tahun 2013, kemudian naik lagi menjadi tiga. Hal ini menunjukka terdapat perbedaan yang signifikan terhadap perhitungan HDI yang sama sekali tidak ada kabupaten/kota di Jawa Timur yang berda pada kategori ini. Kabupaten Malang pada tahun 2010, 2011, 2012 dan 2014 selalu masuk dalam kategori status pembangunan tinggi. Sedangkan pada thun 2013 Kota Surabaya menjadi satu-satunya daerah yang masuk dalam kategori ini.

Dilihat dari komponen I-HDI pada Kabupaten Malang, pada dimensi ad-Dien, an-Nasl dan al-Maal Kabupaten Malang menunjukkan angka yang tinggi. Padahal dari hasil perhitungan HDI Kabupaten Malang hanya berada pada peringkat 25 selama tahun 2010-2014. Hal ini menunjukkan bahwa pengukuran I- 
HDI terhadap pencapaian pembangunan manusia lebih komprehensif dibanding dengan $\mathrm{HDI}$, karena varian indikator yang lebihbanyak sesuai dengan dimensi lima kebutuhan dasar maqashid syariah.

2. Kabupaten/kota dengan status I-HDI menengah atas $(66<1-\mathrm{HDI}<80)$

Berdasarkan perhitungan I-HDI pada tahun 2010 terdapat 19 kota/kabupaten di Jawa Timur dengan status I-HDI menegah atas kemudian di tahun 2011 turun menjadi 12, naik di tahun 2012 menjadi 14, kemudian tahun 2013 turun lagi menjadi delapan, kemudian di tahun 2014 naik lagi menjadi 16. Hasil tersebut menunjukkan bahwa terdapat perbedaan yang cukup signifikan terhadap perhitungan HDI yang mana menunjukkan bahwa sebagian besar kabupaten/kota di Jawa Timur masuk dalam kategori menengah atas.

Sidoarjo yang merupakan salah satu kabupaten di Jawa Timur yang selalu berada kategori status I-HDI menengah atas selama tahun 2010 hingga 2014, jika dilihat dari indikator pembentuk I-HDI, berdasarkan pada angka harapan hidup selama tahun 2010 hingga 2014 secara berturutturut berada pada peringkat ke tiga dengan usia harapan hidup rata-rata 73 tahun. Sementara itu berdasarkan pada indikator pendidikan, rasio angka melek huruf di Kabupaten Sidoarjo berada pada peringkat 24 pada tahun 2010, naik menjadi peringkat empat di tahun 2011, kemudian turun menjadi peringkat lima pada tahun 2012, naik lagi pada tahun 2013 menjadi peringkat empat, dan pada tahun 2014 turun menjadi peringkat delapan namun angka rasionya mengalami peningkatan, dengan persentase rata-rata $97 \%$. Untuk rata-rata lama sekolah di Kabupaten Sidoarjo berada pada peringkat enam pada tahun 2010 dan 2011 secara berturut-turut, kemudian mengalami peningkatan secara terus menerus pada tahun 2012 hingga 2014, menjadi berada pada peringkat empat di tahun 2012 , peringkat di tahun 2013 dan peringkat dua di tahun 2014, dengan rata-rata 9,7 tahun. Angka tersebut cukup relevan mengingat di Kabupaten Sidoarjo sudah banyak tersedia fasilitas pendidikan mulai dari yang mewah hingga sederhana, serta dari aspek ekonomi, peertumbuhan ekonomi di Kabupaten Sidoarjo cukup baik, dilihat dari perkembangan UKM di Sidoarjo yang meningkat.

3. Kabupaten/kota dengan status I-HDI menengah bawah $(50<\mid-\mathrm{HDI}<66)$

Berdasarkan hasil perhitungan I-HDI di Jawa Timur selama periode 2010 hingga 2014, sebagian besar kabupaten/kota di Jawa Timur masuk dalam kategori status pembangunan menengah ke bawah. Pada tahun 
2010 terdapat 15 kabupaten/kota di Jawa Timur yang masuk dalam status pembangunan menengah ke bawah, naik menjadi 22 di tahun 2011 , turun di tahun 2012 menjadi 20, naik lagi di tahun 28 di tahun 2013 lalu turun lagi di tahun 2014 menjadi 19. Hasil perhitungan ini menunjukkan perbedaan yang cukup signifikan dengan hasil perhitungan HDI yang mana menunjukkan sebagian besar dari kabupaten/kota di Jiawa Timur masuk dalam kategori status menengah atas. Adapun lima kabupaten/kota yang selalu berada dalam kategori ini selama tahun 20102014 adalah Kabupaten Ngawi, Kabupaten Madiun, Kabupaten Nganjuk, Kabupaten Magetan dan Kota Malang.

Adannya perbedaan hasil perhitungan $\mathrm{HDI}$ dan I-HDI tersebut tak lepas dari penambahan dimensi dan indikator-indikator yang digunakan dalam proses perhitungan. Seperti diketahui, dalam perhitungan HDI menggunakan pendekatan tiga dimensi yaitu, pendidikan, kesehatan dan pendapatan, dengan empat indikator yaitu angka melek huruf, rata-rata lama sekolah, angka harapan hidup dan pengeluaran perkapita disesuaikan. Sedangkan, dalam perhitungan I-HDI menggunakan pendekatan lima dimensi yaitu agama, jiwa, akal, keturunan dan harta yang terdiri dari 10 indikator, yaitu angka kriminalitas, angka partisipasi siswa sekolah agama, angka harapan hidup, angka melek huruf, rata-rata lama sekolah, angka kelahiran total, angka kematian bayi, pengeluaran perkapita, indeks gini dan indeks kedalaman kemiskinan. Sehingga, dengan menggunakan pendekatan lima dimensi pemeliharaan dalam kebutuhan dasar dan 10 indikator yang mencerminkan dari kelima dimensi tersebut, membuat pengukuran I-HDI lebih komprehensif dalam mengukur pembangunan manusia di dalam suatu daerah, karena kelima dimensi tersenbut merupakan gamabran kebutuhan dasar manusia yang harus dipenuhi.

4. Kabupaten/kota dengan status I-HDI rendah $(I-\mathrm{HDI}<50)$

Pada tahun 2010 jumlah kabupaten/kota yang masuk dalam ketegori status pembangunan rendah berjumlah dua yaitu Kota Pasuruan dan Kota Probolinggo, untuk tahun 2013 hanya berjumlah satu kabupaten yaitu Situbondo.

Kota Pasuruan merupakan kota dengan indikator pendidikan yaitu angka melek huruf juga rata-rata lama sekolah yang berada pada peringkat 9 teratas, masuk ke dalam salah satu provinsi dengan kategori status pembangunan rendah, padahal pada perhitungan HDI Kota Pasuruan masuk dalam kategori menengah ke atas yang mana berada pada peringkat 10 teratas. 
Apabila dilihat dari komponen pembentuk I-HDI, pada dimensi annasl Kota Pasuruan menunjukkan angka yang rendah, hal tersebut disebabkan karena angka kelahiran yang telah disesuaikan dengan persentase angka kematian di kota tersebut berada pada peringkat terendah. Berdasarkan hal ini, dengan kecilnya angka ndex an-Nasl berpengaruh pada turunnya posisi pembangunan Kota Pasuruan ke status pembangunan rendah.

Daerah lain yang termasuk dalam kategori ini adalah Kabupaten Situbondo. Jika dilihat dari komponen pembentukan I-HDI, indeks kedalaman kemiskinan kota tersebut selalu berada pada peringkat 12 teratas. Pengeluaran per kapitanya juga selalu berada peringkat terendah.

\section{Disparitas Pembangunan Manusia}

Pencapaian pembangunan manusia berdasarkan I-HDI, menunjukkan ketidakmerataan, sehingga menyebabkan adanya disparitas pencapaian pembangunan di tiap kabupaten/kota Provinsi Jawa Timur. Disparitas pencapaian pembangunan berdasarkan kabupaten/kota di Jawa Timur dapat dilihat melalui kategori status pencapaian pembnagunan masingmasing provinsi dan selisih antara nilai I-HDI tertinggi dengan nilai I-HDI terendah.

Penyebab disparitas pembangunan manusia selain karena ketidakmerataan juga karena adanya ketimpangan pembangunan ekonomi antar wilayah. Faktor-faktor yang menyebabkan ketimpangan pembangunan ekonomi menurut Emilia \& Imelia adalah sebagai berikut.

1. Konsentrasi kegiatan ekonomi wilayah

2. Alokasi Investasi

3. Mobilitas antar faktor produksi yang rendah antar daerah

4. Perbedaan SDA antar kabupaten/kota

5. Perbedaan kondisi demografis antar kabupaten/kota

6. Kurang lancarnya perdaganan antar kabupaten/kota

Selain karena adanya ketidakmerataan dan ketimpangan pembangunan ekonomi antar wilayah, disparitas pembangunan manusia yang terlihat dari hasil pencapaian pembangunan manusia berdasarkan perhitungan I-HDI ini, juga dikarenakan adanya faktor pemenuhan kebutuhan dasar agama dan keturunan yang berbeda-beda tiap kabupaten/kota, yang mana masuk dalam porsi perhitungan I-HDI. Adapun indikator yang digunakan dalam pengukuran dimensi agama salah satunya adanya angka kriminalitas sebagai cerminan terhadap pelaksanaan salah satu ibadah terpenting dalam rukun Islam yaitu Shalat. Hal tersebut tertuang dalam ayat al-Qur'an Ayat al-Ankabut ayat 45 yang berbunyi sebagai berikut. 


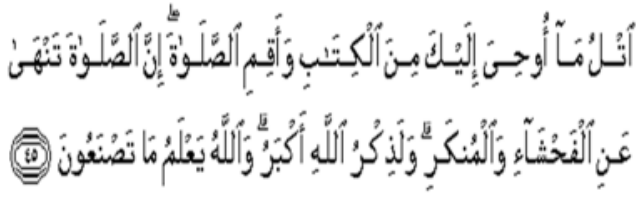

Utlu mā ūhiya ilayka minal kitābi wa aqimișșalāh(ta), innașșalāta tanhā 'anil faḥsyā'i wal munkar(i), wa lażikrullāhi akbar(u), wallāhu ya'lamu mā tașna'ūn(a).

Artinya: "Bacalah apa yang telah diwahyukan kepadamu, yaitu al-Kitab (alQur'an) dan dirikanlah shalat, sesungguhnya shalat itu mencegah dari (perbuatan-perbuatan) keji dan mungkar, dan sesungguhnya mengingat Allah (shalat) adalah lebih besar (keutamaanya dari ibadah-ibadah yang lain), dan Allah mengetahui apa yang kamu kerjakan."

Dimensi keturunan dibentuk oleh indikator angka kelahiran total yang mana angka kelahiran total ini dapat mencerminkan komitmen yang kuat dalam melanjutkan generasi penerus, yang perlu diingat hal ini harus diikuti dengan kualitas kelahiran yang baik dengan ditandainya angka kematian.

\section{Analisis Perbandingan HDI dan I-HDI di Jawa Timur}

1. Sebaran nilai I-HDI lebih beragam dibanding HDI

2. Nilai I-HDI menunjukkan disparitas antar kabupaten/kota lebih besar daripada HDI

3. Perbedaan rangking antar $\mathbf{I}-\mathrm{HDI}$ dan $\mathrm{HDI}$

4. Perbedaan status pembangunan

\section{SIMPULAN}

Berdasarkan dari hasil dan pembahasan yang sudah di jelaskan, maka simpulan yang dapat diambil dari skripsi ini adalah sebagai berikut.
1. Hasil dari pencapaian pembangunan manusia berdasarkan perhitungan I-HDI pada 38 kabupaten/kota di Jawa Timur selama tahun 20102014, dan diukur dengan skala internasional, sebagian besar kabupaten/kota di Jawa Timur termasuk dalam ketegori status pembangunan menengah ke bawah. Selain itu, terjadi disparitas yang cukup jauh antara nilai I-HDI tertinggi dengan yang terendah.

2. Perbedaan yang cukup signifikan antara hasil perhitungan I-HDI dan $\mathrm{HDI}$, di lihat dari perbedaan peringkat tiap kabupaten/kota yang mana dalam HDI berada di peringkat atas namun di hasil perhitungan I-HDI berada di peringkat bawah, juga perbedaan status pembangunan yang dicapai, jika dari perhitungan HDI sebagian besar kabupaten/kota di Jawa Timur masuk dalam kategori status pembangunan menengah atas sedangkan dari hasil perhitungan I-HDI masuk dalam ketegori status pembangunan menengah bawah.

\section{DAFTAR PUSTAKA}

Ahmad, Khursid. 1980. Economic development in Islamic Framework, in Khursid Ahmad, ed., Studies in Islamic Economics, Liecester: The Islamic Foundation and Jeddah: International 
Centre for Reseatch in Islamic Economics, King Abdul Aziz University.

Anto, MH., 2009. Introducing an Islamic Human Development Index (I-HDI) to Measure Development in OIC Countries.

Badan Pusat Statistik

Castrenaningtyas, Mega. 2011. Pengaruh Pertumbuhan Ekonomi dan Disparitas Regional Terhadap Indeks Pembangunan Manusia Jawa Timur: Studi kasus Kawasan Gerbangkertosusuila dan Wilayah Tapal Kuda. Skripsi. Surabaya.Program Sarjana Departemen IImu Ekonomi Universitas Airlangga.

Djamil, Fathurrahman, 1995. Metode Majlis Tarjih Muhammadiyah. Jakarta: Logos,

Emilia \& Imelia, 2006.Modul Ekonomi Regional. Jambi: Jurusan IImu Ekonomi Fakultas Ekonomi Universitas Jambi.

Hafid, Abdul, 2013. Fungsi Sosial BMT UGT Sidogiri Perspektif Maqashid Syariah. Tesis, Surabaya: Program Pascasarjana Universitas Airlangga.

Herdiansyah, Haris. 2010. Metodologi Penelitian Kualitatif untuk IImu-ilmu Sosial. Jakarta: Salemba Humanika.

Leksono, S. 2013. Penelitian Kualitatif IImu Ekonomi. Jakarta: PT. Raja Grafindo Persada.

Moelong, Lexy J., 2004. Metodologi Penelitian Kualitatif. Bandung: Remaja Rosdakarya.

P3El. 2012. Ekonomi Islam. Jakarta: PT. Raja Grafindo Persada, Cetakan Keempat.

Rafsanjani, Haqiqi. 2014. Analisis Islamic Human Development Index Di Indonesia. Tesis, Surabaya: Program Pascasarjana Universitas Airlangga.

Sen, Amartya.1999. Development as freedom. New York: Alfred Knopf.

Srinivasan, T. N. 1994. Humand Development: A New Paradigm or Reinvention of the Wheel? The American Economiv Review. Vol. 84, No. 2. May 1994. 238-243.

Sugiyono, 2013. Metode Penelitian Kuantitatif dan R\&D. Bandung: Alfabeta.

Sumarsono, Soni dan Sahat Marulitua. 2002. Indeks Pembangunan Ekonomi: Review atas Teori Pembangunan Dunia Ketiga, (online), (www.stkip-jb.ac.id, diakses 30 Desember 2009 oleh Mega Castrenaningtyas).
Tambunan, Tulus T.H. 2003. Perekonomian Indonesia : Beberapa Masalah Penting. Jakarta: Ghalia Indonesia.

Todaro, Michael dan Stephen C. Smith. 2003. Pembangunan Ekonomi Di Dunia Ketiga.

United Nations Development Program (UNDP). 